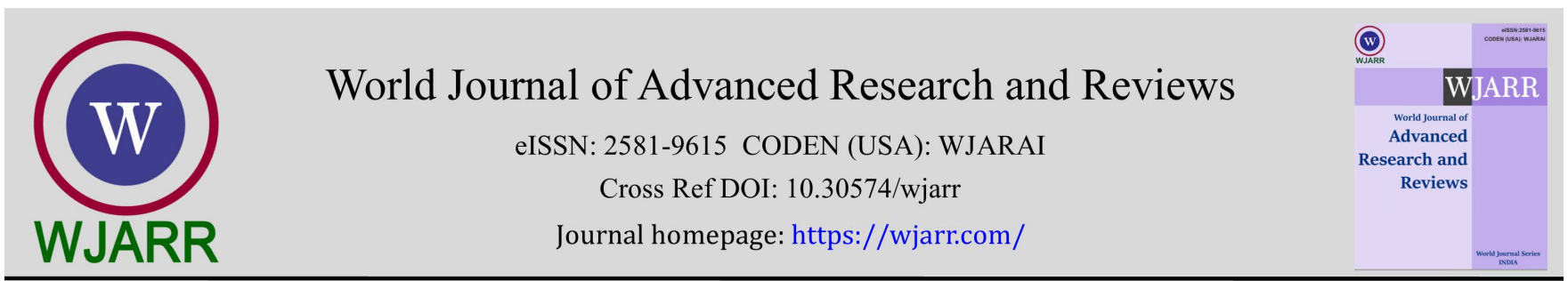

(RESEARCH ARTiClE)

Check for updates

\title{
Assessing government plan and residents' support for agropolitan housing development in the Greater Port Harcourt city, River State, Nigeria
}

\author{
Anthony Donubari Enwin ${ }^{1}$ and Ikiriko Tamunoikuronibo Dawaye 2,* \\ ${ }^{1}$ Department of Architecture, Faculty of Environmental Sciences, Rivers State University of Science and Technology, Port \\ Harcourt, Nigeria. \\ 2 Department of Urban and Regional Planning, Faculty of Environmental Sciences, Rivers State University of Science and \\ Technology, Port Harcourt, Nigeria.
}

World Journal of Advanced Research and Reviews, 2021, 12(01), 097-107

Publication history: Received on 23 August 2021; revised on 27 September 2021; accepted on 29 September 2021

Article DOI: https://doi.org/10.30574/wjarr.2021.12.1.0487

\begin{abstract}
This paper examined, why the Rivers State Government of Nigeria engaged in the Greater Port Harcourt city project as well as individual communities' residents' attitudes in support or against government demand of communities' land for agropolitan residential housing development in the GPH city. Survey questionnaire retrieved from 258 heads of households in 8 selected communities of the Greater Port Harcourt city and key informants' responses were the methods used. The result shows that Greater Port Harcourt City was born to contain and curtail the spill over population, provide good and quality infrastructure and services, upgrade informal settlements and create sustainable residential developments. Respondents' attitude towards land acquisition for self-sustainable agropolitan residential housing development was positive and supportive with modal first to three mention of "More persons will own better homes $(27.3 \%)$, it will enable me own my personal house (18.2\%) and it will solve the housing problem in the area (16.3\%) respectively'.
\end{abstract}

Keywords: Sustainable Development; Agropolitan; Sustainable Housing; Greater Port Harcourt; Residents' Support

\section{Introduction}

The greatest potential for sustainable growth of rural settlements globally lies in the agricultural sector but this is reasonably ironical that the sector in the south-south region of Nigeria is bewildered with the most widespread level of poverty, lack of investment and underdevelopment. Residents and small-scale farmers of rural/ peri-urban communities therefore suffer from access to sustainable housing and good quality of life due to low risk-taking ability and low investment, which leads to low productivity, low market orientation and low value addition which, in turn, nets low margins [13]. The provision of sustainable and affordable housing that cuts across a wide range of incomes has therefore become a major concern among residents, businesses, elected officials, and many community stakeholders and decision makers, globally. Sustainable housing deficiency is a major problem that potentially affects economic development, education, land use, health, business, neighborhood vitality, the environment, transportation, and other aspects of the community.

\footnotetext{
* Corresponding author: Ikiriko Tamunoikuronibo Dawaye

Department of Urban and Regional Planning, Faculty of Environmental Sciences, Rivers State University of Science and Technology, Port Harcourt, Nigeria. 


\section{Literature Review}

The official introduction of housing provision intervention in Nigeria dates back to the colonial administration after the unfortunate outbreak of the bubonic plague of 1928 in Lagos. This led to the establishment of the Lagos Executive Development Board (LEDB) that signified the ushering of Nigerian public housing programmes intervention [17]; [2]. The policies were modest with the ultimate aim of addressing the housing problem at a national scale [15]; not at a state or local government scale. The policy focus then, was on the provision of expatriate quarters [16] and some housing for selected indigenous staff in the Railways, Marine, Police and Armed Forces [2]. The construction of senior civil servant quarters in the capital city of Lagos and regional headquarters like Kaduna, Ibadan and Enugu were some of the practical efforts made and at the same time some form of rent subsidy and housing loans were provided [3]. Most of the housing delivery programs in Nigeria are rarely sustainable since they lack the basic elements of sustainability. [18] asserted that the $20^{\text {th }}$ century saw a lot of failed attempts by the Nigerian government to deliver affordable housing to a majority of her citizens, and worse still for the "No and Low income" groups. [1] argues that housing policies have not been able to meet set targets of affordable housing delivery to the low-income groups and with the high population growth rate and unprecedented unemployment, the insignificant response by government makes the housing deficit more cumbersome. [12] further stated that non availability of mortgage loans, high interest rates, inadequate infrastructure and difficulties in obtaining building plan approvals and Certificates of Occupancy ( $\mathrm{C}$ of $\mathrm{O}$ ) are some factors responsible for the failure of housing policies and programmes in delivering affordable housing to the "No and Low income" groups in Nigeria (as defined in the 2012 Housing Policy Document). According to [6], the idea of affordable and sustainable housing aims to improve the quality of life of individuals as the first step to improve their quality of life for stability, safe and healthy environment with basic services and considers the needs of households whose incomes are not sufficient to allow them to access appropriate housing in the market without assistance at a reasonable price in the short and long term. [6] went ahead to state that sustainable housing targets economic, social and environmental sustainability from planning to implementation and that the most salient characteristics of sustainable development are: 1 . Helping the poor. 2. The idea of cost-effective development, which means that development should not cause deterioration in environmental quality, nor should it at the same time reduce productivity in the long term. 3 . Disease control issues, food security, clean water and shelter for all. 4. Community participation. Therefore, in order to be sustainable, housing initiatives must be economically, socially acceptable, affordable, technologically feasible and environmentally friendly.

With the goal of creating not just sustainable housing, but entire communities that support it, Agropolitan Housing Development which was from a concept proposed by [10] became a means. Agropolitan Housing is a housing development associated with agro-based development meets the objectives of social housing provision [5]. The introduction of this type of social housing thus demands the collaboration of innovative thinkers and recognized leaders, policy makers, philanthropists, developers, business leaders, nonprofits organizations, financiers, city officials, attorneys, and many more who are interested and driven by a collective desire to transform communities, improve the lives of residents of under-served neighborhoods, end a cycle of intergenerational poverty, and set a new course for cities across countries [4]. On this experience, the Rivers State government of Nigeria in 2008 embarked on a vision of building a thriving, economically vibrant and diverse world class competitive and attractive model Garden cum Tourism city with emboldened conscious land use activities that will make its residents enjoy an enviable quality of life, sustainable development, security and good health with enhanced viable economic global integration. The cumulative area for the new city spans eight Local Government Areas of Rivers State, namely- the entire Port Harcourt Municipality and parts of Obio/Akpor, Ikwerre, Etche, Oyigbo, Eleme, Ogu/ Bolo and Okrika Local Government Areas which in total covers an area of approximately 1,900 square kilometres (9,190,000 hectares of land) and to house a projected population of about two million people [9]. This prompted the preparation of a master plan to co-ordinate and integrate a number of projects in the direction of the overall vision. A South African firm by name Arcus GIBB was consulted and appointed for this purpose and the Greater Port Harcourt City Master Plan was prepared. The plan focused to address two prevailing issues which were i. to engage in the activities of urban renewal and transformation of the older city and ii. the building of a new city for the 21st century with high urban quality and planned open spaces that will become a worthy global player that will be an example to other African countries [11]. The Greater Port Harcourt City Development Authority (GPHCDA) was then established on the 2nd of April 2009 by the Greater Port Harcourt City Development Law No. 9 of Rivers State, Nigeria. The GPHCDA was established as a regulatory body with mandate to facilitate the implementation of the Greater Port Harcourt City Master Plan and build the New City called the Greater Port Harcourt City. From the day of its establishment till date, several development proposals and projects have been rolled out; all demanding for the grasp of available land space. One of such is the Public Private Partnership arrangement for the creation of an inclusive and self-sustainable agropolitan residential housing development that will be operated on a private sector model which will successfully engage even the poorest of the poor and provide access to decent affordable housing, employment and revenue generation through conscious involvement in agriculture, light support industries, real estate activities, power generation and distribution, waste management and recycling. The project is an all-inclusive and sustainable agropolitan enclave, to be located in an area zoned for future residential development in 
the Greater Port Harcourt City Master Plan at the Etche-Oyigbo extensions. The objective, first, is to provide affordable housing for members of the target group and then create sustainable, mainly agro-based livelihoods, which will enable beneficiaries to painlessly take care of their housing and other needs. A secondary motive is to create an iconic residential skyline to complement the proposed beautiful townscape of Greater Port Harcourt City. The site will have easy access to the rest of the new city to take advantage of the latter's proposed robust facilities. The target group are young unmarried, newly married without children, the married with young children and generally, energetic people who are willing to make a living in integrated farming, entailing such aspects as livestock production, poultry farming, pig farming, snailry, rabbitry, apiculture, aquaculture and floriculture. Participants of the self-sustainable agropolitan residential housing development must fall within the income groups of "No income" (less than the minimum wage of $\$ 30,000$ monthly), “Low Income” (\$30,000 to \$60000 monthly and “Lower Middle” (\$61000 -90,000 monthly).

\section{Statement of the problem}

In Nigeria, housing deficit is glaring in both rural, peri-urban and urban areas. Delivery of what the 2012 National Housing Policy Document described as Social Housing is still a challenge. Much of what has been described and provided by the government as "low-cost housing estate" is inefficient in the distribution and unsustainable. Rivers state government with a goal to reduce homelessness has in different regimes and government tenures and currently under the Rivers State Housing and Property Development Authority (RSHPDA) provided and managed residential housing estates which mostly are concentrated in the capital city Port Harcourt and some at its peri-urban settlements currently embraced by the Greater Port Harcourt City. Most of these estates are not targeted towards the public but rather, government officials or workers. The housing need of the public has not been dealt with accordingly by the government leaving the challenge to be operated by private investors at the detriment of the public. There is therefore unprecedented homelessness among the 'No-income', 'Low-income and Lower-medium income' groups in the Greater Port Harcourt City area.

\section{Aim of the study}

The aim of this study is to assess government strategy of building sustainable residential communities and residents' support for agropolitan housing development in the Greater Port Harcourt City, Rivers State, Nigeria.

\section{Objectives of the study}

The objectives of the research are to:

- Ascertain the Rivers State government reason for the establishment of the Greater Port Harcourt City

- Ascertain individual communities' residents' attitudes in support of government's desire and demand of communities' land for agropolitan residential housing development in the GPH city.

- Ascertain residents perceived benefits of agropolitan residential housing development in the GPH city

- Ascertain individual communities' residents' attitudes against government's desire and demand of communities' land for agropolitan residential housing development in the GPH city.

\section{Description of the study area (Greater Port Harcourt City)}

Under the leadership of former Governor, Chibuike Amaechi, plans were announced for the creation of a new city to be called Greater Port Harcourt City. The total area of the Greater Port Harcourt City is 1,900 km², spanning all or parts of eight Local Government Areas in Rivers State, including Ogu Bolo, Eleme, Ikwerre, Etche, Obio/Akpor, Okrika and Okrika. (See Figure 1 and 2). The Greater Port Harcourt City Development Authority (GPHCDA) was established by law in April 2009 with a mandate to facilitate the implementation of the Greater Port Harcourt City Master Plan and build the new city. The Greater Port Harcourt City hosted several of the events at the 17th National Sports Festival tagged "Garden City Games" at the recently completed Adokiye Amiesimaka Stadium. Greater Port Harcourt City has a total land mass that spans eight (8) Local Government Areas namely, Port Harcourt City, Obio/Akpor, Etche, Ikwerre, Ogu Bolo, Eleme and Oyigbo. Total number of communities in the GPHC are 71 as shown in Table 1. 


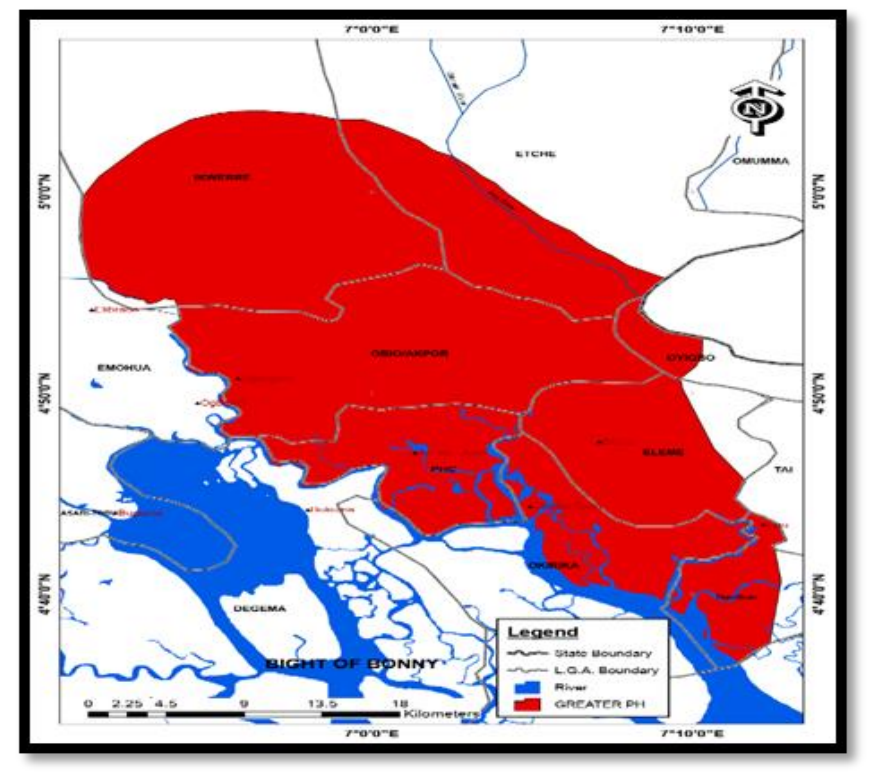

Figure 1 Map of Greater Port Harcourt City; (Source: [11])

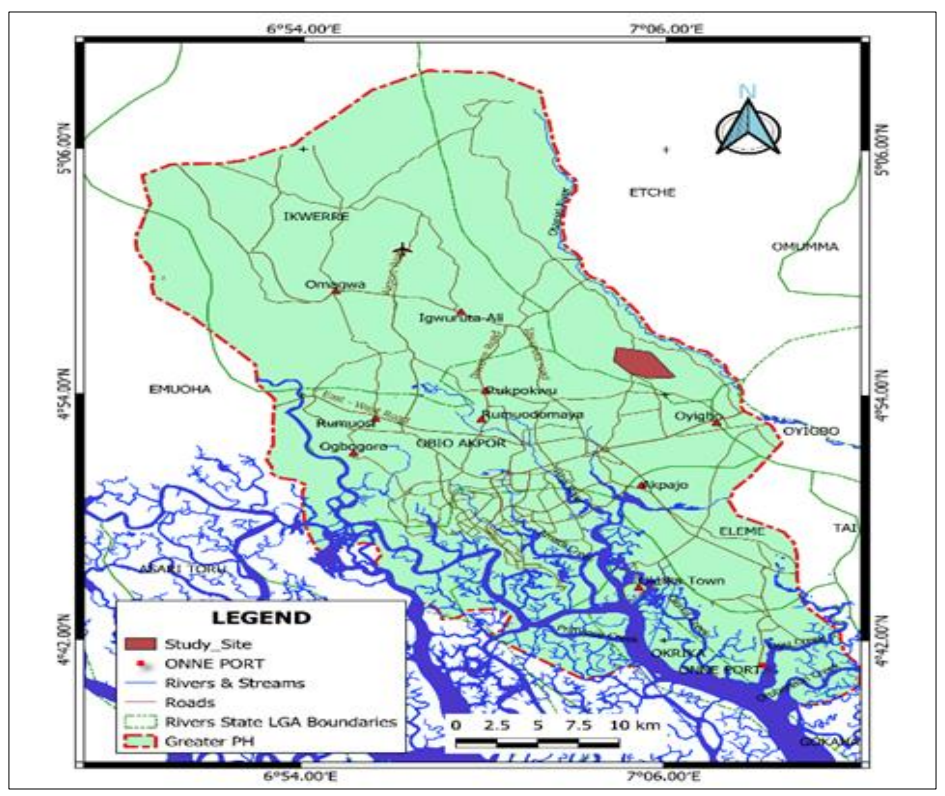

Figure 2 Map of Greater Port Harcourt City showing Proposed Site for Agropolitan Project; (Source: [11])

\section{Research methodology}

The population for which generalization was made concerning the result of this study is the sum total number of resident in the Greater Port Harcourt city area. Heads of households and relevant public officers served as the unit of analysis. The stratified multi-stage sampling procedure [14] was adopted for the extraction of sampled population of head of households in selected communities of GPHC (See Tables 1 and 2). Two stages were therefore involved.

Stage 1-- Obtaining a 10\% (a priori decision) sample of the component communities of GPHC in each stratum. The number in each stratum was rounded to one whole number to ensure representation of each stratum.

Stage 2 --Obtaining the number of households to be studied after applying the [20] formula which aided the researcher to determine the appropriate number of cases to be studied at the precision level of $5 \%$.

Mathematically the [20] formula was used as given by: 
Where,

$$
\mathrm{n}=\mathrm{N} / 1+\mathrm{N}\left(\mathrm{e}^{2}\right)
$$

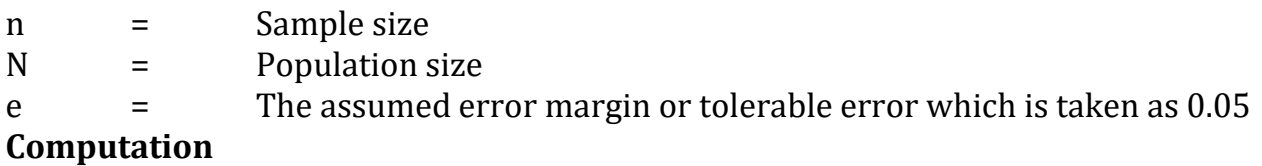

$\mathrm{n}=29,093 / 1+29,093\left(0.05^{2}\right)=29,093 / 1+29,093(0.0025)=29,093 / 1+72.7=\quad 29,093 / 73.7$
$=\quad 395$

Table 1 Sampling Details 1

\begin{tabular}{|c|c|c|c|c|}
\hline S/No. & $\begin{array}{l}\text { Local Govt. } \\
\text { Area (Stratum) }\end{array}$ & Names of GPHC Communities & $\begin{array}{l}\text { No. of GPHC } \\
\text { Communities }\end{array}$ & $\begin{array}{l}\text { 10\% Sample } \\
\text { With Rounding }\end{array}$ \\
\hline 1 & $\begin{array}{l}\text { Port Harcourt } \\
\text { Municipality }\end{array}$ & $\begin{array}{l}\text { Port Harcourt Township, Rumuibekwe, } \\
\text { Abuloma, Amadi-Ama, Diobu, Elakahia, } \\
\text { Nkpolu Oroworukwo, Ruumukalagbor, } \\
\text { Ogbunabali, Orogbum, Oromineke, } \\
\text { Oroworukwo }\end{array}$ & 12 & 1 \\
\hline 2 & Obio/ Akpor & $\begin{array}{lrr}\text { Eneka, } \quad \text { Rumuodomaya, } & \text { Elelenwo, } \\
\text { Rukpokwu } & \text { Rumuosi, } & \text { Iriebe, } \\
\text { Rumuagholu, } & \text { Ogbogoro, } & \text { Eliozu, } \\
\text { Rumuokwurusi } & & \end{array}$ & 10 & 1 \\
\hline 3 & Etche & $\begin{array}{l}\text { Igbo-Etche, Abara, Elele-Etche, } \\
\text { Umuebulu, Chokocho, Ikwerengwo }\end{array}$ & 6 & 1 \\
\hline 4 & Ikwerre & $\begin{array}{l}\text { Igwuruta, Igwuruta-Ali Omagwa, Ipo, } \\
\text { Aluu, Ozuoba, Omademe }\end{array}$ & 7 & 1 \\
\hline 5 & Ogu-Bolo & $\begin{array}{l}\text { Ogu Town, Bolo Town,Wakama, Agokien, } \\
\text { Mbikiri, Owo-Ogono, Iwokiri }\end{array}$ & 7 & 1 \\
\hline 6 & Okrika & $\begin{array}{l}\text { Okrika, Okujagu, Abam-Ama, Omodara- } \\
\text { Ama, Kalio, George, Obo, Ele, Ibuluya, } \\
\text { Ogoloma, Donkiri, Mabegbeboko }\end{array}$ & 12 & 1 \\
\hline 7 & Eleme & $\begin{array}{l}\text { Nchia, Ebubu, Esama, Eteo, Onne, Ogale, } \\
\text { Alode, Aleto, Akpajo, Alesa }\end{array}$ & 10 & 1 \\
\hline \multirow[t]{2}{*}{8} & Oyigbo & $\begin{array}{l}\text { Oyigbo Town, Komkom, IzuomaAyama, } \\
\text { Okoloma, Umusia, Iwuoma- Estate }\end{array}$ & 7 & 1 \\
\hline & Total & & 71 & 8 \\
\hline
\end{tabular}

The representative number of cases for questionnaire administration was 395 heads of households. The systematic probability sampling [14] was applied to the ordered list of households in the 8 communities, which constituted the probability sampling frame. Since the sampling fraction was approximately 1\%, a random start was made in the interval 1 - 100. Thereafter, every 100th case was picked until the probability sample size of 395 was achieved. There were 63 non-response cases, yielding a non-response rate of $16 \%$. This translates to 332 valid cases but analysis will be based on percentage distribution of categories of respondents' monthly household income due to inclusiveness of the "no income", "low income" and "lower middle income" categories. Adopting the pragmatist philosophical approach known as pragmatism [19]; [8] which welcomes a mixed methodology, the study also engaged key informants interview (KII) of relevant public officials. This was achieved judgmentally by interviewing directors of Greater Port Harcourt City Development Authority and former staff of Arcus Gibbs. 
Table 2 Sampling Details 2

\begin{tabular}{|c|c|c|c|c|c|c|c|}
\hline $\mathbf{S} / \mathbf{N}$ & Stratum & $\begin{array}{l}\text { Names of } \\
\text { Selected } \\
\text { Communities }\end{array}$ & $\begin{array}{c}\text { Population } \\
\text { (1991 } \\
\text { Census) }\end{array}$ & $\begin{array}{c}2019 \\
\text { Population } \\
\text { (Projected } \\
\text { @6.5\% } \\
\text { Annual } \\
\text { Growth } \\
\text { Rate) }\end{array}$ & $\begin{array}{l}\text { Total No. of } \\
\text { Households } \\
\text { from listing }\end{array}$ & $\begin{array}{c}\text { No. of } \\
\text { Households } \\
\text { from on } \\
\text { Yamane } \\
\text { formulae }\end{array}$ & $\begin{array}{c}\text { Sampling } \\
\%\end{array}$ \\
\hline 1 & $\begin{array}{l}\text { Port } \\
\text { Harcourt } \\
\text { Municipality }\end{array}$ & $\begin{array}{l}\text { Mgbundukwu } \\
\text { (Mile } 2 \text { Diobu) }\end{array}$ & 9,600 & 55,682 & 8,808 & 120 & 1.5 \\
\hline 2 & Obio/Akpor & Rumuodomaya & 4,548 & 25,519 & 4,828 & 65 & 1.5 \\
\hline 3 & Etche & Abara & 1,866 & 10,823 & 1,940 & 26 & 1.5 \\
\hline 4 & Ikwerre & Igwuruta-Ali & 2,805 & 16,269 & 2,480 & 34 & 1.5 \\
\hline 5 & Ogu-Bolo & Wakama & 2,717 & 15,759 & 2,266 & 31 & 1.5 \\
\hline 6 & Okrika & Okujagu & 5,794 & 33,785 & 3,191 & 43 & 1.5 \\
\hline 7 & Eleme & Akpajo & 5,195 & 30,298 & 3,092 & 42 & 1.5 \\
\hline 8 & Oyigbo & Okoloma & 3,474 & 20,149 & 2,488 & 34 & 1.5 \\
\hline \multicolumn{3}{|l|}{ Total } & 35,999 & 208,284 & 29,093 & 395 & 1.5 \\
\hline
\end{tabular}

\section{Findings of the study}

\subsection{Reasons for the Establishment of the Greater Port Harcourt City}

Key informants (former Arcus Gibb staff members) presently working with the Rivers State government revealed that Greater Port Harcourt City was born to contain and curtail the spill over population, provide good and quality infrastructure and services, reduce traffic congestion and enhance flow, clean up the old Port Harcourt city in terms of refuse removal, define urban precincts and critical urban elements that improve urban form, de-densify residential cluttering, upgrade informal settlements, create sustainable residential and mixed land use developments and reestablish the garden city status.

The pioneer Administrator of the Authority states that the whole GPHC project was "a call to duty with the mission to build a world class Garden City, thriving economically, operating efficiently, prosperously and assuring its residents a quality of life envied for its peacefulness, comfort and sustainability" [7].

Summation of responses from Directors in Greater Port Harcourt City Development Authority on the challenges faced in the acquisition of land for projects are as follows:

- $\quad$ The step for property acquisition in the GPHC is cumbersome

- Land had to be acquired from communities, body corporate, families and individuals who happens to claim ownership of the land.

- Compensation had to be paid before possession of the land

- There is serious need of funds and funding challenge from the Rivers State Government

- The local communities had to be involved in the survey and setting out process of the land

- Enough social mobilization had to take place in order to quell the interest of opposition parties

\subsection{Respondents' Support for Development of Agropolitan Residential Housing Development}

Since Agropolitan Housing Development is an inclusive project for the "no income", "low income" and "lower middle income", only respondents (and households) that fall into categories 1 to 4 in Table 3 (the shaded area, totaling 258) qualify for further analysis (with respect to opinions and perceptions of the Agropolitan Housing Development). 
Table 3 Percent Distribution of Categories of Respondents' Monthly Household Income

\begin{tabular}{|c|c|c|c|}
\hline S/No. & Income Category $(\mathrm{N})$ & $\mathbf{N}$ & $\%$ \\
\hline 1 & Less than 30,000 & 70 & 21.1 \\
\hline 2 & $30,000-49,999$ & 62 & 18.7 \\
\hline 3 & $50,000-69,999$ & 59 & 17.8 \\
\hline 4 & 70,000 - 99,999 & 67 & 20.2 \\
\hline 5 & $100,000-129,999$ & 38 & 11.4 \\
\hline 6 & $130,000-159,999$ & 28 & 8.4 \\
\hline \multirow[t]{2}{*}{7} & $160,000-189,999$ & 4 & 1.2 \\
\hline & Missing data & 4 & 1.2 \\
\hline \multicolumn{2}{|r|}{ Total } & 332 & 100 \\
\hline
\end{tabular}

Although proper compensations were made for land acquisition, respondents show willingness to give out their property for the agropolitan residential housing development. Respondents were asked if they would support development of sustainable social housing in the area. The modal response was "Yes", accounting for 78.7\% of the distribution.

Table 4 Reasons for the Support of Agropolitan Housing Development (Percentage Distribution of First, Second and Third Mentions)

\begin{tabular}{|c|c|c|c|c|}
\hline S/No. & Reason & $\begin{array}{c}\% \\
\text { First Mention } \\
(\mathrm{N}=\mathbf{2 0 3})\end{array}$ & $\begin{array}{c}\% \\
\text { Second } \\
\text { Mention } \\
(\mathrm{N}=203)\end{array}$ & $\begin{array}{c}\% \\
\text { Third } \\
\text { Mention } \\
(\mathrm{N}=203)\end{array}$ \\
\hline 1 & The scheme will not work & 3.2 & 0 & 0 \\
\hline 2 & It will help the low-income earners & 15.0 & 12.8 & 7.3 \\
\hline 3 & It will enable me own my personal house & 10.2 & 18.2 & 11.4 \\
\hline 4 & $\begin{array}{l}\text { It will enable me provide accommodation for my } \\
\text { children }\end{array}$ & 3.2 & 7.4 & 4.9 \\
\hline 5 & It will create employment & 2.7 & 2.0 & 5.7 \\
\hline 6 & More persons will own better homes & 27.3 & 11.5 & 16.3 \\
\hline 7 & Affordable houses for all & 4.3 & 17.6 & 2.4 \\
\hline 8 & It will lead to reduction in rent by landlords & 2.7 & 7.4 & 11.4 \\
\hline 9 & $\begin{array}{l}\text { People will stop paying rent instead paying for their } \\
\text { personal homes }\end{array}$ & 3.7 & 3.4 & 11.4 \\
\hline 10 & It will solve the housing problem in the area & 25.7 & 5.4 & 16.3 \\
\hline 11 & It will help me move to a cleaner neighbourhood & 1.1 & 9.5 & 7.3 \\
\hline 12 & New estate will decongest the neighbourhood & 1.1 & 3.4 & 0 \\
\hline 13 & Instalment payment is good & 0 & 1.4 & 2.4 \\
\hline 14 & $\begin{array}{l}\text { The unemployed can take advantage of the } \\
\text { opportunity }\end{array}$ & 0 & 0 & 3.3 \\
\hline \multicolumn{2}{|r|}{ Total } & 100 & 100 & 100 \\
\hline
\end{tabular}


Table 4 shows the modes among the first, second and third mentioned reasons which are as follows:

- Modal first mention: "More persons will own better homes" (27.3\%)

- Modal second mention: "It will enable me own my personal house" (18.2\%)

- Modal third mention: "It will solve the housing problem in the area" (16.3\%)

\subsection{Respondents' Perceived Benefits of the Agropolitan Housing Development}

Respondents were asked to state the perceived benefits of Agropolitan Housing Development. Their responses are detailed in Table 5. The modal first, second and third mentions were "Easy/Installment repayment plan" (9.9\%), "Better Neighbours" (6.9\%) and "Well planned estate" (4.6\%).

Table 5 Perceived Benefits of Agropolitan Housing Development

\begin{tabular}{|c|l|c|c|c|}
\hline S/No. & Item & $\begin{array}{c}\text { First } \\
\text { Mention } \\
\mathbf{( N = 2 0 3 )}\end{array}$ & $\begin{array}{c}\text { Second } \\
\text { Mention } \\
\text { (N=203) }\end{array}$ & $\begin{array}{c}\text { Third } \\
\text { Mention } \\
\text { (N=203) }\end{array}$ \\
\hline & & $\%$ & $\%$ & $\%$ \\
\hline 1 & Easy Instalment payment & 9.9 & 2.3 & 1.9 \\
\hline 2 & Peace of Mind & 3.8 & 4.6 & 1.1 \\
\hline 3 & Well-planned estate & 0 & 4.6 & 4.6 \\
\hline 3 & It will eliminate landlord and tenant problems & 1.9 & 0 & 2.7 \\
\hline 4 & It will enable me plan well & 1.9 & 0 & 0 \\
\hline 5 & Ineed my own accommodation as a young man & 1.9 & 1.5 & 0 \\
\hline 6 & It will give me privacy & 1.5 & 0 & 0.4 \\
\hline 7 & Youths can own homes early in their lives & 4.2 & 1.5 & 1.1 \\
\hline 8 & Everything will be within the state & 1.1 & 1.1 & 1.5 \\
\hline 9 & Employment will be provided & 0 & 1.1 & 0.8 \\
\hline 10 & Low income earners can now own homes & 0 & 2.7 & 1.1 \\
\hline 11 & Good environment & 2.7 & 2.3 & 1.1 \\
\hline 12 & New and modern houses & 3.8 & 4.6 & 3.5 \\
\hline 13 & Housing for all & 2.3 & 0 & 0.4 \\
\hline 14 & Work and home will be close & 3.1 & 0 & 2.3 \\
\hline 15 & Better neighbours & 3.1 & 6.9 & 4.2 \\
\hline 16 & Basic amenities will be present & 1.1 & 3.8 & 3.8 \\
\hline 17 & Security will be provided & 0.8 & 0 & 5.0 \\
\hline 18 & Working and paying for the house is good & 0 & 3.8 & 0 \\
\hline 19 & Recreational facility will be present & 0.8 & 2.3 \\
\hline 20 & Missing Data & 52.7 & 41.6 & 61.8 \\
\hline & & 100 & 100 & 100 \\
\hline & & & 0 \\
\hline
\end{tabular}

(Source: Researcher's Field Survey, February, 2020) 


\subsection{Perceived Disadvantages and Reasons for Not Supporting Agropolitan Housing Development}

Table 6 shows the percentage distribution of Perceived Disadvantages and Reasons for Not Supporting Agropolitan Housing Development

Table 6 Perceived Disadvantages and Reasons for Not Supporting Agropolitan Housing Development

\begin{tabular}{|c|c|c|c|c|}
\hline \multirow[t]{2}{*}{ S/No. } & \multirow[t]{2}{*}{ Item } & $\begin{array}{c}\text { First } \\
\text { Mention } \\
(\mathrm{N}=55)\end{array}$ & $\begin{array}{l}\text { Second } \\
\text { Mention } \\
(\mathrm{N}=55)\end{array}$ & $\begin{array}{c}\text { Third } \\
\text { Mention } \\
(\mathrm{N}=55)\end{array}$ \\
\hline & & $\%$ & $\%$ & $\%$ \\
\hline 1 & It can distract one from building another house & 0.8 & 0 & 0 \\
\hline 2 & The salary may not be good enough & 0.4 & 0 & 0 \\
\hline 3 & Maintenance of estate will not be easy & 0.8 & 0.4 & 1.5 \\
\hline 3 & Length of time to work to own a house will be long & 4.6 & 0.8 & 0.4 \\
\hline 4 & The estate might be far from the city & 0 & 2.7 & 0.4 \\
\hline 5 & No choice in terms of building design & 0.4 & 1.1 & 2.7 \\
\hline 6 & Stigmatization (Low cost/ low income estate) & 2.3 & 0.4 & 0 \\
\hline 7 & The programme might fail & 0.4 & 1.5 & 0 \\
\hline 8 & I will be bound/ tied to the contract duration & 0.8 & 0 & 0.8 \\
\hline 9 & Missing Cases & 89.7 & 93.1 & 94.3 \\
\hline & Total & 100 & 100 & 100 \\
\hline
\end{tabular}

The modal perceived disadvantages of the proposed agropolitan housing development for the first, second, and third mentions were; "Length of time to work to own the house will be long" (4.9\%), "Estate may be far from the city" (2.7\%) and "No choice in terms of building design" (2.7\%), respectively.

\section{Discussion of Findings}

Building sustainable residential communities demands serious investment capital on land resources acquisition, property owners' compensation and public awareness and sensitization. Both primary data from heads of households and key informants; and secondary data all attest to the quantum of land need, positive behavior towards agropolitan housing development as a sustainable way for their area speedy development. Although, there are economic, sociocultural, technical and environmental factors which poses challenges to land acquisition, the residents are willing and ready to give out their land for an inclusive and self-sustainable agropolitan residential housing development that will be operated on a private sector model which will successfully engage even the poorest of the poor and provide access to decent affordable housing, employment and revenue generation through conscious involvement in agriculture, light support industries, real estate activities, power generation and distribution, waste management and recycling.

\section{Conclusion}

This study has ascertained the reason why the Rivers State government established the Greater Port Harcourt City. It has also found out residents' attitudes in support for and against government's desire and demand of communities' land and their perceived benefits of agropolitan residential housing development within their locality. The findings indicate that Greater Port Harcourt City was born to contain and curtail the spill over population, provide good and quality infrastructure and services, reduce traffic congestion and enhance flow, de-densify residential cluttering, upgrade informal settlements and create sustainable residential and mixed land use developments. Most of the respondents' attitude towards land acquisition for self-sustainable agropolitan residential housing development was positive and supportive with modal first to three mention of "More persons will own better homes (27.3\%), it will enable me own my personal house $(18.2 \%)$ and it will solve the housing problem in the area $(16.3 \%)$ respectively'. Top of residents 
perceived benefits of agropolitan housing development were in the order of the modal first, second and third mentions which were "Easy/Installment repayment plan" (9.9\%), "Better Neighbours" (6.9\%) and "Well planned estate" (4. 6\%).It was of no doubt that some residents saw the development in a negative light and do not support for its implementation. Top of their reasons on the list of first, second, and third mentions were; "Length of time to work to own the house will be long" (4.9\%), "Estate may be far from the city" (2.7\%) and "No choice in terms of building design" (2.7\%), respectively.

The study found out that firstly, more of the study area residents are in support of the agropolitan housing development. This means that there will be a strong community-government alliance in the implementation of the project. Secondly, when the residents are interested and in full awareness and participation in a project, it means that they will go all out and protect the project. The third implication is that, with the acceptance and motivation of the community, such project will rarely fail. Having a working knowledge of why some people are not in support of the project therefore become a guide against misbehavior on the part of the government, private partners and communities' stakeholder groups.

\section{Compliance with ethical standards}

\section{Acknowledgments}

We unanimously give our sincere appreciation to God Almighty for life and for enabling us enjoy focus as we make this publication.

\section{Disclosure of conflict of interest}

We do not have any conflict of interest.

\section{References}

[1] Ademiluyi A. Public Housing Delivery Strategies in Nigeria: A historical perspective of policies and programs. Journal of Sustainable Development in Africa. 2010; 12(6): 153-161.

[2] Aribigbola A. Conceptual Issues in Housing Provision in Nigeria in Akinbamijo, O. B., Fawehinmi, A. B., Ogunsemi, D. R., and Olotuah, A. O. (Eds.) Effective Housing in the 21st Century. The Environmental Forum FUTA. 2000; 1-8.

[3] Bello A. Review of the Housing policies and programmes in Nigeria. International Journal of Contemporary Research and Review. 2019; 10(02): 20603-20616.

[4] Bonnie C, Kelsey M. Best Practices for Affordable Housing. City of Ashville N. C. 2015.

[5] Burkey T. Social housing over the horizon: Creating a contemporary social housing system. National Housing Conference 2005 Perth October 27-28, Institute for Social Research, Swinburne University of Technology. 2015; 1-15.

[6] Choguill CL. The search for policies to support sustainable housing. Habitat international. 2007; 31(1): 143-149.

[7] Cookey-Gam A. An Overview of the Greater Port Harcourt City Master Plan and Opportunities in Building a World Class City over the Next 20 Years. Greater Port Harcourt Development Authority: Port Harcourt, Nigeria. 2010.

[8] Creswell JW, Plano Clark VL. Designing and conducting mixed methods research, Thousand Oaks, California, Sage Publications. 2011.

[9] Ede PN, Owei OB, Akarolo CI. Does the greater Port Harcourt master plan 2008 meet aspirations for Liveable City? In Proceedings of the ISOCARP Congress. 2011.

[10] Friedmann J, Douglass M. Agropolitan development: towards a new strategy for regional planning in Asia Growth Pole Strategy and Regional Development Policy: Asian Experiences and Alternative Approaches Eds Lo, F, Salih, K (Pergamon Press, Oxford). 1978;163-192.

[11] GPHCDA. Greater Port-Harcourt City Development Masterplan 2008. Greater Port- Harcourt City Development Authority, Government of Rivers State of Nigeria, Accus Gibbs. 2008.

[12] Ibem EO, Amole 00. Evaluation of Public Housing Programmes in Nigeria: A Theoretical and Conceptual Approach. The Built Environment Review. 2010; 3: 88-116.

[13] ITC. Sustainable Agriculture and Value Networks: An Opportunity for Small Growers to Export Successfully? Alvarez, G. ITC Executive Forum 2006, International Trade Centre UNCTAD/WTO. Geneva, Switzerland. 2006. 
[14] Kish L. Survey Sampling. New York, NY: Wiley. 1965.

[15] Omange GY, Udegbe MI. Government involvement in housing. In Effective Housing in 21st Century Nigeria, Environmental Forum, Federal University of Technology Akure, Nigeria. 2000; 9-14.

[16] Oni SB. Managing the Rapid Growth of Cities in Nigeria. Oluseyi Boladeji Company; 1989.

[17] Onibokun A. A critical review of the Nigerian government housing policy and programmes. 1975.

[18] Onyike JA. Addressing the urban Housing problems of Nigeria in the 21st century. In 29th Annual Conference of the Nigerian Institution of Estate Surveyors and Valuers. 2012; 21-26.

[19] Tashakkori A, Teddlie C, Teddlie CB. Mixed Methodology: Combining Qualitative and Quantitative Approaches. 1978; 46.

[20] Yamane T. Statistics: An introductory analysis. 1967. 